\title{
Diffusion and glocalization: dialectical tensions for Wal-Mart de México
}

\author{
Elizabeth Minei · Jonathan Matusitz
}

Published online: 6 February 2013

(C) International Network of Business and Management 2013

\begin{abstract}
This paper analyzes the role of Wal-Mart in Mexico by following two globalization models that are dialectical pulls: diffusion and glocalization. While diffusion refers to the spread of ideas and practices from one culture to another (Rogers, Diffusion of innovations, 2003), glocalization refers to the strategic choices made by multinational corporations (MNCs) to adapt their products and services in foreign markets to influence local consumer acceptance-where the actual "Wal-Martization" is occurring. Essentially, the dialectical tensions between diffusion and glocalization represent tensions between aspirations to preserve local cultures (with their customs and preferences) and the growing pressures of globalization (Williams, Commun Stud 53(1):1-3, 2002).
\end{abstract}

Keywords Culture $\cdot$ Diffusion $\cdot$ Globalization $\cdot$ Glocalization $\cdot$ Mexico $\cdot$ Wal-Mart

\section{Introduction}

This paper analyzes the role of Wal-Mart in Mexico by following two globalization models that are dialectical pulls: diffusion and glocalization. While diffusion refers to the spread of ideas and practices from one culture to another (Rogers 2003), glocalization refers to the strategic choices made by multinational corporations (MNCs) to adapt their products and services in foreign markets to influence local consumer acceptance-where the actual "Wal-Martization" is occurring. Catering to the customs and tastes of local cultures has been Wal-Mart's strategy for almost

\section{E. Minei}

University of Oklahoma, Norman, OK, USA

\section{J. Matusitz ( $\square)$}

University of Central Florida-Seminole State College,

100 Weldon Blvd, Partnership Center (\#3009), Sanford, FL 32773, USA

e-mail: matusitz@gmail.com 
two decades-e.g., in Canada, China, Japan, and the U.K. (e.g., Matusitz and Forrester 2009; Matusitz and Leanza 2009; Matusitz and Reyers 2010). Essentially, the dialectical tensions between diffusion and glocalization represent tensions between aspirations to preserve local cultures (with their customs and preferences) and the growing pressures of globalization (Williams 2002).

Mexico was the first country in which Wal-Mart ventured overseas (Del Carmen Valecia 2007; Spulber 2007). It is called Wal-Mart de México (Reuters 2008). When the company first entered the Mexican market in 1991, it attempted to enforce Wal-Martization on local Mexican customs. Put simply, it maintained its U.S. strategy of management practices, employee standards, low wages, EDLP (everyday-low pricing) for buyers, fierce pressure on suppliers, anti-union policies, and aggressive expansionism tendencies. History has shown that Wal-Mart's hardnosed, unyielding approach has failed in a few countries, such as Germany and Korea, causing these ventures to eventually pull out (Landler and Barbaro 2006). Diffusion and glocalization have proven to be a blended formula that has made Wal-Mart de México a successful business undertaking. Wal-Martization, in this fashion, not only advances the economic situation in Mexico but also acts as a catalyst on the cusp of cultural change as well.

This analysis is important for two reasons. On the one hand, it takes a look at a giant corporation (that ventured into a developing nation) from theoretic perspectives that few scholars have adopted. On the other hand, in recent years, there has been scant consideration of the Mexican market and its role in the global retailing and finance process. This lays the foundation for the heart of this analysis: the importance of WalMart de México to both diffuse and glocalize. First, the authors explain how the corporation became successful thanks to its diffusion strategies. The three key themes that describe the diffusion strategies are as follows: (1) diffusion practices: modernized operations, (2) diffusion practices: standardized supplier relations, and (3) diffusion practices: introduction of consumer financial procedures. At the same time, this paper describes the three glocalization strategies that Wal-Mart has adopted in Mexico to grow and become the largest private employer in that nation. These glocalization strategies are (1) adaptation to local Mexican customs, (2) adaptation to Mexican consumer habits, and (3) adaptation to Latin American store formats. This analysis ends with a discussion section that also offers suggestions for future research.

\section{Globalization perspectives}

Often described as the greatest human intervention in nature since the invention of agriculture, the Columbian exchange was the largest-ever international exchange of humans, ideas, plants, products, and, in particular, food (Crosby 2003; Grennes 2007; Nunn and Qian 2010). This particular example of globalization epitomizes the notion of "increasing scale, extent, variety, speed and magnitude of international cross-border, social, economic, military, political and cultural interrelations" (Wiarda 2007, p. 3). The modernized version of the Columbians exchange is that of multinational corporations (MNCs) looking for new venues of products and new markets to bolster flagging growth of current operations (Selling to the Developing 
World 2003). Wal-Mart Stores, Inc., is one of the MNCs looking for opportunity to supplement their bottom line. Wal-Mart is the world's most privately controlled economic institutions with sales that consistently rank in the first and second spot for publicly traded company in the U.S. and in the world. Wal-Mart has impacted wage rates, prices, and economies on a local, national, and global scale (Fishman 2006). International sales alone accounted for 24 percent of Wal-Mart's $\$ 374.5$ billion in net sales for 2008 (Clark and Edelson 2008). For more than a decade, Wal-Mart has managed to transfer two-thirds of its capital expenditures to international high-growth markets (Zimmerman et al. 2008). While critics claim that the Wal-Martization of the world is detrimental to business, society, and culture, other scholars suggest that Wal-Mart contributes economic prosperity to individuals, communities, and even entire countries (Welch and Welch 2006). Now, let us have a better understanding of Wal-Martization.

\section{Wal-Martization: a description}

Occasionally known as the Wal-Mart effect, Wal-Martization exemplifies the ways in which Wal-Mart has changed the face of business, work, communities, and everyday life in the U.S. and around the world (Fishman 2006). This sentiment rings true, considering that Wal-Mart is the largest retailer in both Mexico and Canada, and the second largest grocer in England. Estimates suggest that worldwide, in a given year, 7.2 billion people will go to a Wal-Mart store (Fishman 2006). "WalMart International," Wal-Mart's official Website, proudly exhibits the exploits and profits of its 4,000 stores in the U.S. and 3,000 stores in the other parts of the world (Marquard 2006). Wal-Mart's promise to bring goods and products to consumers under the motto of "faster, better, cheaper" and "bigger, and more globally" aids in the perpetuation of Wal-Mart as a behemoth among retailers.

The successful venture of Wal-Mart in Mexico is in maintaining many of the standard operating procedures that proved to be a successful business model in the U.S. These factors include technological advances (i.e., its sophisticated satellite system that can track cargo loads to the smallest detail), global sourcing, the growth of global consumer segments (da Rocha and Dib 2002), and organic growth (Steil and Hinds 2009). Organic growth is the method by which an MNC expands as a result of increased output, sales, or both (Bahadir et al. 2009). MNCs like to follow the strategy of replicating domestic operations in the rest of the world due to familiarity and tried-and-true success while preserving operational control and maintaining identity and brand awareness (Coe and Hess 2005). Organic growth is undertaken in two ways. The first expands in surrounding existing markets, or through hierarchical development, specifically, expanding through major to minor nodes of retail activity (Hernandez and Biasiotto 2001). The concept of organic growth will allow Wal-Mart the status of being the first trillion-dollar-a-year company with supercenters spanning every two miles (Butler 2005). Wal-Mart topped Fortune's Global 500 list with 2010 sales of $\$ 408$ billion (O'Keefe and Burke 2010). 
Wal-Martization is synonymous with the image of an unstoppable discount, "big box" retailer, one that comes into town, reshapes shopping habits, and drains the viability of traditional local shopping areas or mom-and-pop shops (Fishman 2006). A major bulk contributing to mom-and-pop "drainage" lies with Wal-Mart's competitive pricing. Wal-Mart reduces prices by half simply because it has the power and the ability to do so (Bosshart 2007). Wal-Mart's focus on a single core value-delivering low prices-created what became the largest and most powerful company in history. Traditionally, what results from the core value are notably low wages, pressure on suppliers, cheaply produced products both in quality as well as price, and off-shoring of jobs (Fishman 2006). The Wal-Martization of Mexico is felt through the enforcing of new lighting and AC systems at its Wal-Mart stores. The objective is to advocate U.S.-style comfort and ease when shopping (Abboud and Biers 2007).

\section{Wal-Mart de México}

Organizational survival in a foreign market does not occur without the right decision, the right management practices and the right timing. Before the mid1980s, Mexican producers of consumer goods were heavily protected causing strained or non-existent relations with international retailers-primarily those in the U.S., whose strength was located in dealing with suppliers. In the mid-1980s, the Mexican economy began entertaining the idea of international retail relations. As tariffs fell following the remaining half-decade, Mexican retailers began to offer more consumer goods imported from the U.S. (Javorcik et al. 2008). Upon the decision of the North American Free Trade Agreement (NAFTA) to lock in place commercial policy reforms while extending national treatment to foreign investors, U.S.-based retail chains began to focus more and more on the untapped resources of Mexican market (Javorcik et al. 2008). In 1985, in response to a call for commercial policy reform, Mexico joined the General Agreement on Tariffs and Trade (GATT). In doing so, Mexico was able to legally partner with international businesses once NAFTA had been signed in 1992 and implemented in January 1994. By the 1990s, Mexico had enabled itself to integrate with the global economy in general, and specifically with opening its markets in conjunction to the U.S. (Javorcik et al. 2008).

The opening of its doors to international business relations was an invitation for Wal-Mart to enter the Mexican market. Having only entered into Mexico in 1991, Wal-Mart has secured a foothold in Mexico's economic makeup. Presently, records indicate that Wal-Mart operates retail outlets in six formats in Mexico: Wal-Mart, Bodega Aurrera, Superama, Sam's Club, Suburbia, and VIPs. As of April 2010, there were a total of 1479 Wal-Mart retail outlets operating in Mexico. In December 2009, Wal-Mart in Mexico announced the acquisition of Wal-Mart's operations in Central America from Wal-Mart Stores and two minority partners. In early 2010, the transaction was completed and Wal-Mart Mexico became Wal-Mart Mexico and Central America (Food Retail Industry Profile 2010). Increasingly, Wal-Mart has relied on purchases by consumers in Mexico to improve its sales growth (Hudson 
and Campoy 2007). The company enjoyed same-store sales growth of 7.1 percent in the fourth quarter (Gogoi 2007). As of 2006, Wal-Mart became the biggest retailer and private employer of the entire country of Mexico (Smith 2006). The omnipresence of Wal-Mart stores in that nation has pushed critics of WalMartization to coin the term "Texification" of Mexico or "Tex-Mex" Wal-Mart (Barone 2006).

\section{Diffusion}

Coined by Everett Rogers (2003), the term diffusion (what he actually called Diffusion of Innovations) refers to "a process in which an innovation is communicated through certain channels over time among members of a social system" (p. 5). More specifically, with regards to organizations, diffusion is the process by which an idea, practice, or object is launched globally among varied and highly localized cultures (Flight et al. 2011). This is not to say that a given innovation is "objectively" new, measured by a lapse in time. Rather, it is the perceived newness to the potential adopter that counts (Rogers 2003). This is the phenomenon that occurred for Wal-Mart upon opening in Mexico. Understandably, the entry of a corporation into a foreign market entails attention to detail, and closer cultural examination than if it were to compete in its own domestic market (Kotler 1986).

Wal-Mart is a good example of a successful corporation. Sam Walton launched his Wal-Mart business in Bentonville, Arkansas, in 1962 (Lavallee and Boyer 2006). Time after time, Wal-Mart in Arkansas diffused from small towns to larger ones-a pattern called reverse hierarchical diffusion. Then, from Arkansas, the company diffused to neighboring states-what is called contagious hierarchical diffusion (Swanson 2008). Thus, the diffusion of Wal-Mart is one of diffusing up (rather than down) the urban or metropolitan hierarchical structure (Brunn 2006). This blending of contagious and reverse hierarchical diffusion has allowed WalMart, within four decades, to become the world's most successful retailer (May et al. 2007). Wal-Mart had $\$ 1$ billion annual sales in 1979 , then $\$ 1$ billion sales in a week in 1993, and $\$ 1$ billion in sales every day in 2001 (Brunn 2006).

Diffusion of Wal-Martization implies that the success of Wal-Mart in Mexico was based on local consumers' willingness to set aside cultural traditions in favor of the domestic blueprint utilized in the U.S. The three key diffusion practices are as follows: (1) diffusion practices: modernized operations, (2) diffusion practices: standardized supplier relations, and (3) diffusion practices: introduction of consumer financial procedures.

\section{Diffusion practices: modernized operations}

As noted earlier, Wal-Mart has a reputation for implementing the U.S. blueprint for management practices. Successful management practices that helped to modernize operations were (1) a tendency toward aggressive expansion, (2) overhauling retail operations, and (3) adjusting consumer experiences. The first modernized operation of aggressive expansion, has in the past, caused major trouble for Wal-Mart and has 
jeopardized the international relations with other franchising attempts (Evans et al. 2000). Yet, contradictory to the documented trouble, much of Wal-Mart's success in Mexico can be attributed to the fact that Wal-Mart started big to begin with. Because of no discernable cause, Wal-Mart's arrival in a Mexico was at an advantage due to a country that was grossly "under-stored." Common practice among retailers before Wal-Mart's arrival was a traditional high/low pricing system based on periodic discounts rather than consistently low prices (Tilly 2005).

The peso devaluation of 1994-95 offered Wal-Mart a unique opportunity to buy (at an extremely low price) a controlling share of Cifra, which at the time was the country's largest and best-run retail chain (Landler and Barbaro 2006). Following the purchase, Wal-Mart put more than $\$ 1$ billion toward opening 120 new stores in Mexico (Tilly 2005). The practice of aggressive expansion paved the way for MNCs to emerge in the local market. In 1997, Wal-Mart bought controlling interest in Aurerra (part of the Mexican commercial group Cifra) and thusly, Wal-Mart de México (also called Wal-Mex) was formed (Javorcik et al. 2008). Taking over Cifra provided a massive foundation to build from. Benefits to this strategic move were that the management remained in place, knew the market well and cut down on the processes that drain time and resources from replacing the workforce (Landler and Barbaro 2006).

Another modernized operation that contributed to the success of Wal-Mart in Mexico was that of overhauling retail operations. Before the entry of Wal-Mart in Mexico, the ratio of retail workers was one out of every five (Tilly 2005). A huge number of retail workers toil in the Mexican informal sector, estimated by INEGI (Mexican Statistical Office) to employ 29 percent of the Mexican nonagricultural workforce, of whom nearly a third work in commerce and restaurant (The Economist 2001). In addition, while female employees account for the majority of the retail workforce in both countries, Mexico accounts for a 44 percent higherthan-average proportion of female retail employees comparatively (Tilly 2005). Falling in line with the traditional wage discrepancy of "women's" jobs, belowaverage wages are commonplace in both countries for retail employment (Tilly 2005). Only two of the eight other major Mexican economic industries (construction and agriculture and fisheries) pay less. Reports also indicate that wholesale was a higher paid industry than retail (Tilly 2005).

From doing no business at all in Mexico in 1991, to present day, Wal-Mart in Mexico is both the nation's largest retailer and grocer in the country-bigger than its next three competitors combined (Fishman 2006). In 2002, the company created 8,000 new jobs-half of the permanent new jobs in Mexico (Weiner 2003). WalMart sells nearly $\$ 6$ billion worth of food in Mexico, more than anyone else in Mexico (Weiner 2003). The company is also Mexico's most important retailer and largest private employer with almost 150,000 workers (Harner 2007). In addition to the impact on its own numerous employees, a business of Wal-Mex's size and visibility also has spillover effects on other jobs in the retail sector and on low-skill jobs in general. Wal-Mart, traditionally criticized for providing low-wage, exploitative jobs, has surpassed this negative expectation by paying wages slightly above average in the Mexican retail industry. On top of higher wages, Wal-Mart de México offers pay and benefits comparable to its competitors (Tilly 2005). 
Wal-Mart indicated that the treatment of its employees is so well that the workers do not want to unionize, and that the wages workers are paid are superior its Mexican competitors (Weiner 2003).

The last aspect of modernizing consumer experiences is that of adjusting consumer experiences. Modernization of the retail landscape from the consumer perspective is driven by the rise of an urban middle class drove growth (Moreau 2009). Before the entry of Wal-Mart in Mexico, consumer purchasing was modeled after the styles dating back thousands of years. Customary outlets for consumers consisted of open-air markets located in city centers and managed by city governments (Weiner 2003). Tradition dictated that retailers sold wares from small stalls. Mobile street markets (tianguis) that change location from day to day (similar to the ferias libres in Chile or feiras livres in Brazil) were considered the norm in Mexico. Communities and city neighborhoods dedicate plaza market day where, on one day of the week, the tianguis shows up and sell a variety of products similar to that of a supermarket, but usually of lower quality and at negotiable prices. Mexican consumers were accustomed to purchasing perishables from tianguis and selfservice stores, including supermarkets and modern convenience stores. This format and the subsequent expectations have changed with the presence of Wal-Mart in Mexico. Nowhere outside the U.S. are its stores as numerous as in Mexico, where the scope and scale of its operations have grown to resemble its dominion in the U.S. (Weiner 2003). Wal-Mart is the only major international operators in grocery retailing in Mexico (Moreau 2009). In 2002, the influence of U.S. purchasing habits became apparent with 2,221 of the modern convenience stores in operation in Mexico. This number is expected to expand.

Reductions in trade barriers made Mexico a more attractive market for Wal-Mart. The entry of Wal-Mex has led to a number of major changes in modernizing operations in Mexico. The implementation of an aggressive expansion plan, revamped retail operations that led to better wages and employee benefits, and the adaptation of a new version of the market itself breathed new life into the economic body of Mexico. The dissemination of the latest retail techniques to other retail chains brought with it increased competition in the retail sector. Once Wal-Mex was established, it changed the way suppliers of consumer goods interacted with retailers (Javorcik et al. 2008). The growing dominance of Wal-Mex helped induce two fundamental changes in the Mexican retail sector because it changed the way it interacted with its suppliers (Javorcik et al. 2008). The following section outlines the adaptations to supplier relations in Mexico as a result of establishment of WalMart; waste reductions in bringing goods to market; scale economy exploitation by those Mexican-owned and foreign producers that sold to Wal-Mex; greater incentives for small-scale local producers to adopt innovations; movement toward marginal cost pricing, even among the major brand (Javorcik et al. 2008).

Diffusion practices: standardized supplier relations

The Wal-Mart way was implemented in more than just operations. Wal-Mart, in an effort to deliver the cheapest goods to consumers, developed a reputation for keeping suppliers under pressure to deliver. Relationships between suppliers and 
stores before the arrival of Wal-Mart were based on store dependencies on suppliers for most deliveries with little experience in demanding discounts from supplier (Tilly 2005). The presence of Wal-Mex drastically revised the supplier/store relationship so much so that now centralized warehouses were responsible for coordinating a delivery system-and there were steep fines in place for missed deliveries (Tegel 2003). Another requirement that changed the face of Mexican delivery operations was the regulation imposed to the method of delivery. Delivery trucks had scheduled appointments and drivers were required to carry standard identification cards (Tegel 2003). Shipments subsequently underwent changes as well. Standardized palettes rentable from Wal-Mex were required for all deliveries and goods were systematically shrink wrapped to protect the contents of the shipments. Trucks were also vulnerable to audits conducted by a third-party for quality control (Javorcik et al. 2008).

Large scale suppliers are not the only ones having to undergo change to insure survival. Typically, farming practices within Mexico range from small-scale familyowned holdings to large commercial farming operations (Agricultural Products Industry Profile 2010). Top revenue-producing crops in Mexico include corn, tomatoes, sugar cane, dry beans, and avocados. The major buyers of market-ready products, such as fruit and vegetables, are large grocery retailers such as Wal-Mart, whereas the major buyers of products requiring processing, such as cereal grain, are wholesale dealers and food processing companies. From a local perspective, selling to supermarkets is an attractive alternative for small farmers for whom the larger offers relief from the unattractive prospects in stagnant local markets targeting poorer consumers (Schwentesius and Gomez 2002). Customary Wal-Mart relations with suppliers are characterized as "stark" and "hard-nosed" both in terms of the bargaining environment and in terms of the number of negotiable contract features (Tegel 2003). Suppliers have little choice, but to conform, because Wal-Mex controls such a vast share of the retail market. The result is a take-or-leave it offer commonly seen in U.S. business practices (Fishman 2006). Wal-Mart's entry did have a dramatic effect on Mexico's formal retail sector particularly on the relationship between retailers and suppliers. As in the U.S., Wal-Mex has extracted deep discounts from suppliers and passed them on to customers. As a result, it has put small shops out of business and has forced other large Mexican chains to adopt similar practices (Gelpern 2007).

Wal-Mex's implementation of relations with suppliers diffused from the model used in domestic relations with suppliers in the U.S. According to Tegel (2003), in the early 2000s, Wal-Mex was "the only Mexican retail chain that has its own centralized distribution system. Suppliers can deliver their goods just once to any Wal-Mex depot scattered across the country, rather than to each individual store" (p. 4). This method was effective if not hard nosed. Again, diffusion of U.S. practices proved to be necessary in maintaining systematic and organized operating procedures. The adaptation of Mexico to except the diffusion of these standard operating procedures has created a radical change in the way business is done in Mexico (Weiner 2003). The last section outlining the globalization is contributing to radical changes is in the introduction of Wal-Mex's consumer financial procedures. 
Diffusion practices: consumer financial procedures

In August 2006, Wal-Mart applied for a banking license in Mexico (Adler 2006). By November 2006, Wal-Mart's Mexican subsidiary received approval to open a bank. Unlike the effort for Wal-Mart to start a bank in the U.S., the application faced little opposition in Mexico (Gelpern 2007). This was in part because, in Mexico, Wal-Mart's banking endeavor would be regarded as a catalyst in increasing competition in what has traditionally been considered a concentrated banking sector. Nearly 75 percent of the Mexican population is without a bank account and has never been in possession of one (Adler 2006). Banking authorities speculate that,

“They probably keep their money under their mattresses, and they have very... low access or no access at all to credit. Our initial target would be to try to work with other bank competitors in "bankarizing" the Mexican population that doesn't have access to financial products and services." (p. A1).

Wal-Mart's target population is the underserved (Gelpern 2007). By 2010, WalMart Stores Inc. had been offering savings accounts and credit cards through its three-year-old Banco Wal-Mart de México Adelante franchise south of the border. Even with 160 branches in place by the end of 2010, Mexico's economy lagged behind counterparts in other developing countries in providing credit to the economy with bank lending to the private sector at about 20 percent of GDP even after the recent lending surge (Engen 2010). The bank does not offer car loans or mortgages, instead offering a credit card so customers can buy Wal-Mart merchandise (Tyler 2010). Wal-Mart is experimenting with a "blended retail point-of-sale approach" to banking, where any customer contact, such as buying groceries in the checkout lane, offers an entree to meet potential banking needs (Engen 2010). In the last couple of years, Banco de Wal-Mart has opened almost 250 branches, with plans to add a hundred more by the end of the year, all courting people who are new to banking (Tyler 2010). Debt comes at a high price with Banco de Wal-Mart's credit card with annual interest rates set at 60 percent. Any attempts at regulation, such as capping interest rates, are feeble due to the fact that Wal-Mex is it is the biggest employer in the country (Tyler 2010). When the dust settles, WalMart's Mexican banking foray will likely emerge as an important case study in financial globalization (Gelpern 2007).

\section{Glocalization}

Extensive research by international retailing has accounted for the unique challenges and opportunities facing companies that attempt to permeate the market on a global scale (Bennison and Gardner 1995; Burt 1991; Davies and Sanghavi 1995; Goldman 1981; Ho and Sin 1987; Kaynak 1980; Lord et al. 1988; Martenson 1987; McGoldrick and Ho 1992; Muniz-Martinez 1998; Skonieczny 2010; Sparks 1995; Tilly 2005; Treadgold 1991, Tyler 2010; Weiner 2003). Many of these cases only succeeded based on the principles of glocalization. 
Glocalization, a term coined by Robertson (1994), refers to the set of strategies adopted by an MNC-e.g., a retailer-to sell products and services by catering to the local culture in which the corporation is located (Kraidy 2002). Glocalization has been necessary for Wal-Mart in its multiple international ventures (e.g., Brazil, India, Japan, and the U.K.) (Matusitz and Forrester 2009; Matusitz and Leanza 2009; Matusitz and Reyers 2010). The approach that Wal-Mart in Mexico took was similar. In some cases, it was not the U.S. blueprint of management approaches, employee practices, low wages, EDLP (every-day-low pricing) for buyers, fierce pressure on suppliers, anti-union policies, and aggressive expansionist tendencies.

This section describes, in detail, the three glocalization strategies that Wal-Mart has adopted in Mexico to grow and become the largest private employer there. Those glocalization strategies are (1) adaptation to local Mexican customs, (2) adaptation to Mexican consumer habits, and (3) adaptation to Latin American store formats.

\section{Adaptation to Local Mexican customs}

Several years after Wal-Mart entered the Mexican markets, the company tried hard to assimilate to local Mexican customs. For instance, in the southwestern part of Mexico, people speak a Mesoamerican language called Zapotec. Wal-Mart used it in its stores to be more appealing to local consumers (Cornell 2010). It recruited Zapotec-speaking interviewers to make local applicants feel "at home." At sales meetings, the traditional Wal-Mart cheer is now recited in Zapotec ("Gimme a W!" is "Dane $\mathrm{Na} \mathrm{Ti}$ W!"). Ads and commercials are presented in Zapotec by female speakers in their indigenous flowing skirts and ornate blouses. Inside Wal-Mart, consumers can go shopping while hearing the noisy trumpets and cymbal clashes of Mexican melodies, called sones de Tehuantepec (Lyons 2007).

In fashion, Wal-Mart is now displaying food items which feature a bigger range of Hispanic food brands. It has sold products (e.g., cakes, dresses, etc.) specifically for quinceañeras, the traditional celebration in which Hispanic girls turn 15 (Zimmerman and Hudson 2006). In 2007, as prices for U.S. corn skyrocketed, the price of Mexico's corn tortilla skyrocketed too. Wal-Mart, then, provided much effort to maintain tortilla prices low as the company knew that corn tortilla is what millions of Mexican poor are fed with (Lyons 2007). Mexico's corn tortillas are of extreme importance to Mexicans. These tortillas - while of inferior quality — can be purchased in all types of retail outlets. Yet, at Wal-Mart and other major food retailers, they can be bought in the largest volume (Gabel and Boller 2000). This tortilla crisis became a free "publicity" occasion for Wal-Mart; millions of new local consumers went there to buy cheaper tortillas (Lyons 2007).

Adaptation to Mexican consumer habits

To adapt to Mexican habits even more, Wal-Mart has managed to blend U.S. products and services with local Mexican consumer tastes. At the typical Wal-Mart store of Monterrey, in northeastern Mexico, a security guard will directly approach consumers to forbid them from taking notes-as it is not allowed in large Mexican 
outlets (Morais 2004). Too, a tourist shopping in a Wal-Mart store in Monterrey will see that he or she has to first walk by rows of random goods (e.g., oranges, salad crackers, and flour) that are meticulously promoted as less expensive than those of rival Soriana. Soriana, a food store retail chain, is Mexico's second biggest retailer (Brunn 2006). Put simply, inside Wal-Mart de México stores, sales receipts from Soriana-with its higher prices underlined in color-are flamboyantly taped to shelves. No other rival chain is "revealed" by Wal-Mart in this fashion. Such comparative advertising is a glocalization strategy that Wal-Mart has used a lot (Morais 2004).

Deemed the largest retailer among poor and working-class households in the U.S., Wal-Mart is well known for its everyday-low-pricing (EDLP) policy. In fact, the company's PR campaigns frequently stress the price savings that consumers can experience when Wal-Mart opens stores in a foreign market (Brunn 2006). WalMart has launched the Mexican version of EDLP-precios bajos todos los dias. Many products are actually much cheaper than those their U.S. counterparts and those of other Mexican stores (Biles et al. 2007). It is certain that Wal-Mart's yearly revenues would be higher if the company sold its products in Mexico at the price set in the U.S. At the same time, Wal-Mart is also aware that the GDP per capita in Mexico is just roughly $\$ 13,000$ a year, according to the CIA World Factbook (2011). By lowering prices of thousands of basic products (from tomatoes to diapers), Wal-Mart has helped improve the standard of living of millions of middleclass and poor Mexicans (Lyons 2007).

\section{Adaptation to Latin American store formats}

For the past decade, Wal-Mart's strategy for rapid expansion has been to develop the "no-frills" Bodega Aurrera format. Bodega Aurrera is not intended to compete with upscale supermarkets. Rather, it is aimed at adapting to low-income and working-class cultures and being a strong rival to local stores, urban markets, and small retail (Chavez 2002). It is a plain, low-cost grocery chain, which Wal-Mart tailored from its venture with Cifra to be appealing to shoppers in middle-size and smaller cities of southern and central Mexico (Biles et al. 2007). When Wal-Mart launched its Bodega Aurrera stores to fulfill small-town needs, protesters gathered around the building for a few days to express their anger about the new store's likelihood of putting local vendors out of business and wearing down the local culture. However, as most inhabitants wanted the store, the protests dwindled (Lyons 2007).

Wal-Mart's Bodega Aurrera serves low-income consumers; its Wal-Mart supercenters are for midlevel customers. Conversely, its Superama outlets sell higher-quality groceries (Zimmerman and Hudson 2006). While Bodega Aurrera stores offer fewer items of foodstuffs (mostly food and housewares), Superama supercenters are located in wealthier parts of Mexico City and its suburbs, and target quality and convenience. Superama stores have 70 percent of sales from food (Coleman 2004). A third store format, the Wal-Mart's Suburbia store, is an apparel store designed for middle-income shoppers (Tilly and Galván 2006). 
With respect to format, Wal-Mart de México has also improved its success by glocalizing the layout and plans for its stores. For example, when customers were put off by the sight of a large parking lot surrounding one of the company's big box stores-most Mexicans do not have cars-a shuttle service was introduced to move shoppers from the store exit to a spot where they can take the bus or pay for a cab. From this moment on, most parking lots at Wal-Mart de México have had this specific parking design (Mexico's Retail Goliath 2002).

\section{Discussion and future directions}

What this paper has demonstrated is that the dialectical tensions between the neologisms of diffusion and glocalization are part of a framework of globalization that presupposes, simultaneously, openness to Mexican differences and obliviousness to it. The dialectical tensions between diffusion and glocalization lead to the deduction that they can be at opposite poles. This goes along with Kuhn's (2009) claim that cultures are not shut down to change; they borrow from foreign values and philosophies and reinterpret local cultural customs. At the same time, to reach their long-established goals, cultures are also set to follow their own cultural schema. From this vantage point, both diffusion and glocalization are efficient for the thriving Wal-Martization of Mexico.

By concentrating on dialectical tensions, this Wal-Mart case study helps clarify the intricacies of interdependence in globalization (Jones 1994). The dialectical tensions between diffusion and glocalization are the fundamental dialectics of global and intercultural dynamics taking place at present. These tensions can be related to (although not condensed to) tensions between wishes to preserve local cultures (with their customs and habits) and the increasing pressures of globalization (Williams 2002). Essentially, the dialectical tension in the Wal-Martization of Mexico is a tension "between the forces of global modernism and local preservation" (p. 2). Contemporary flows toward globalization imply that, increasingly, people are getting exposed to continuously evolving cultural practices throughout their lives (Erbert et al. 2003).

On the one hand, Wal-Mart adapted a position of diffusion to Wal-Martization practices and standard operating procedures that have been utilized in the U.S. since the origination of the store itself. The emphasis on modernizing operations, from aggressive expansion plans for organic growth, to the overhauling of a country's lagging retail culture, to the methods by which local marketing practices were established, led to the successful diffusion of ideas about managing business. Further explorations into the diffusion of practices can be observed in Wal-Mart's standard relations with suppliers. Converting a disorganized system, one without regulations or standard practices to the system in place in current ventures not only contributed to the success of the store but also to the standardization of practices that challenged the way in which the an entire country handles business. Wal-Mart, while notorious in the U.S. for low wages and exploitation of workers, has challenged those accusations in Mexico by paying competitive wages and offering benefits to its employees. Finally, the adaptation and willingness to diffusion have 
been implemented in a banking system that will bring standardized financial procedures to a country where three-quarters of the population is without this modern convenience.

On the other hand, the three glocalization strategies adopted by Wal-Mart de México have made it the largest retailer in Mexico; they have also allowed local Mexican consumers to be exposed to Wal-Mart's products and services. The result for Wal-Mart de México is a company that is hybridized and that differs from its U.S. counterpart. Wal-Mart managers certainly know the concept of "diffusion" but not "glocalization." Nevertheless, they are well cognizant of the importance of a multinational corporation (MNC) to be understanding of local tastes and adapt to their local needs. As we have seen, Wal-Mart deemed it necessary to recruit Zapotec-speaking females in their local flowing skirts and ornate blouses. With respect to Mexican products and consumer habits, what is inside Mexican Wal-Mart stores is not the same as in U.S. stores (e.g., corn tortillas and the ban from taking notes in higher-quality Wal-Mart outlets).

The homogeneity-heterogeneity dichotomy is just one outlet for future culturally driven research concerning the role of Wal-Martization in the corporation's attempt to conquer the globe. It might be pertinent to address the following questions: Is there too much Wal-Martization at the expense of the existing culture? What is lost when corporations (and cultures) succumb to the blueprint of other entities? In a similar vein, could Wal-Mart lose its luster by constantly glocalizing when entering foreign markets? Gladwell's (2003) Tipping Point has a few ideas as to how an entity on the cusp of major trend can cause involvement as permeating as an epidemic. With such a relatively new endeavor, it might prove interesting for future directions to ask: What major social changes occur due to the implementation of an entity that can potentially change the lives of 75 percent of a given countries population?

The globalization of retailing is a process that is both complex and ongoing. The venture of Wal-Mart overseas may cause a change-for good or ill-among local cultures, but, as this analysis exemplifies, the company's application of diffusion and willingness to adopt foreign principles has improved its situation both economically and socially. Globalization truly provides hope for success in the face of increasing global competition.

\section{References}

Abboud, L., and Biers, J. (2007, August 27). Business goes on an energy diet. Wall Street JournalEastern Edition, 250(48), R1-R4.

Adler, J. (2006). Wal-Mart discusses branch plan For Mexico. American Banker, 171(149), 1-3.

Agricultural Products Industry Profile. (2010). Global Agricultural Products. Retrieved February 20, 2011 from http://www.reportlinker.com/p0171441/Global-Agricultural-Products.html

Bahadir, S. C., Bharadwaj, S. S., \& Parzen, M. M. (2009). A meta-analysis of the determinants of organic sales growth. International Journal of Research in Marketing, 26(4), 263-275.

Barone, M. (2006). Edging to the right. U.S. News and World Report, 141(2), p. 49.

Bennison, D., \& Gardner, H. (1995). Internationalisation of limited line discount grocery operations. In P. J. McGoldrick \& G. Davies (Eds.), International retailing: Trends and strategies (pp. 191-206). London: Pitman Publishing. 
Biles, J., Brehm, K., Enrico, A., Kiendl, C., Morgan, E., Teachout, A., et al. (2007). Globalization of food retailing and transformation of supply networks: Consequences for small-scale agricultural producers in southeastern Mexico. Journal of Latin American Geography, 6(2), 55-75.

Bosshart, D. (2007). Cheap? The real cost of living in a low price, low wage world. London, England: Kogan Page.

Brunn, S. (2006). Wal-Mart world: The world's biggest corporation in the global economy. New York: Routledge.

Burt, S. (1991). Trends in the internationalisation of grocery retailing. International Review of Retail, Distribution and Consumer Research, 1(4), 487-515.

Butler, D. (2005). India's new millennium salvo to Wal-Mart and resistance to re-colonization. Social Policy, 36(1), 28-31.

Chavez, M. (2002). The transformation of Mexican retailing with NAFTA. Development Policy Review, 20(4), 503-513.

CIA World Factbook. (2011). Mexico. Washington, D.C.: Central Intelligence Agency.

Clark, E., \& Edelson, S. (2008, November 3). Wal-Mart to grow in emerging regions. DNR: Daily News. Record, 38(44), p. 14.

Coe, N. M., \& Hess, M. (2005). The internationalization of retailing: Implications for supply network restructuring in East Asia and Eastern Europe. Journal of Economic Geography, 5(4), 449-473.

Coleman, R. W. (2004). Globalization of food retailing: The case of Latin America. Latin American Business Review, 4(4), 23-41.

Cornell, D. (2010). American Madonna: Crossing borders with the Virgin Mary. Maryknoll, NY: Orbis Books.

Crosby, A. W. (2003). The Columbian exchange: Biological and cultural consequences of 1492. Westport, CT: Praeger.

da Rocha, A., \& Dib, L. A. (2002). The entry of Wal-Mart in Brazil and the competitive responses of multinational and domestic firms. International Journal of Retail and Distribution Management, 30(1), 61-74.

Davies, G., \& Sanghavi, N. (1995). Market innovation and internationalisation: The success of Toys 'R' Us. In P. J. McGoldrick \& G. Davies (Eds.), International retailing: Trends and strategies (pp. 207-218). London: Pitman Publishing.

Del Carmen Valecia, M. (2007). Mara del Carmen Valencia. Business Week Online, p. 17.

Engen, J. (2010). Wal-Mart gets serious. New York: Source Media.

Erbert, L. A., Perez, F., \& Gareis, E. (2003). Turning points and dialectical interpretations of immigrant experiences in the United States. Western Journal of Communication, 67, 113-137.

Evans, J., Treadgold, A., \& Mavondo, F. T. (2000). Psychic distance and the performance of international retailers: A suggested theoretical framework. International Marketing Review, 17(4), 373.

Fishman, C. (2006). The Wal-Mart effect and a decent society: Who knew shopping was so important? Academy of Management Perspectives, 20(3), 6-25.

Flight, R. L., Allaway, A. W., Wan-Min, K., \& D’Souza, G. (2011). A study of perceived innovation characteristics across cultures and stages of diffusion. Journal of Marketing Theory and Practice, 19(1), 109-126.

Food Retail Industry Profile. (2010). Global food retail. Retrieved February 20, 2011 from http://webcache. googleusercontent.com/search?q=cache:xmfxT3-pgDQJ:marketpublishers.com/report/consumers_ goods/food_beverage/

Gabel, T. G., \& Boller, G. W. (2000). Assessing divergent disciplinary views of the globalization of consumption: An exploratory, cross-sectoral, and ethnographic examination of consumer-choice dynamism resulting from the influx of new forms of retailing. Advances in Consumer Research, 27(1), 166-172.

Gelpern, A. A. (2007). Wal-Mart Bank in Mexico: Money to the masses and the home-host hole. Connecticut Law Review, 39(4), 1513-1538.

Gladwell, M. (2003). The tipping point: How little things can make a big difference. Boston: Little, Brown and Company.

Gogoi, P. (2007). Wal-Mart goes abroad for growth. Business Week Online, 1, 6.

Goldman, A. (1981). Transfer of a retailing technology into the less developed countries: The supermarket case. Journal of Retailing, 57(2), 5-29.

Grennes, T. (2007). The Columbian exchange and the reversal of fortune. CATO Journal, 27(1), 91.

Harner, J. (2007). Globalization of food retailing in Guadalajara, Mexico: Changes in access equity and social engagement. Journal of Latin American Geography, 6(2), 33-53. 
Hernandez, T., \& Biasiotto, M. (2001). Retail location decision-making and store portfolio management. Canadian Journal of Regional Science, 24(3), 399-421.

Ho, S. C., \& Sin, Y. M. (1987). International transfer of retail technology: The successful case of convenience stores in Hong Kong. International Journal of Retailing, 2(3), 36-48.

Hudson, K. (2007, February 23). Wal-Mart presses suppliers to enhance their diversity. Wall Street Journal-Eastern Edition, 249(44), p. A12.

Hudson, K., and Campoy, A. (2007, August 29). Hispanics' hard times hit Wal-Mart. Wall Street Journal-Eastern Edition, 250(50), p. A8.

Javorcik, B., Keller, W., \& Tybout, J. (2008). Openness and industrial response in a Wal-Mart world: A case study of Mexican soaps, detergents and surfactant producers. World Economy, 31(12), $1558-1580$.

Jones, T. S. (1994). A dialectical reframing of the mediation process. In J. P. Folger \& T. S. Jones (Eds.), New directions in mediation (pp. 26-47). Thousand Oaks, CA: Sage.

Kaynak, E. (1980). Transfer of supermarketing technology from developed to less developed countries: The case of Migros-Turk. Finnish Journal of Business Economics, 29(1), 1.

Kotler, P. (1986). Global standardization: Courting danger. Journal of Consumer Marketing, 2, 13-15.

Kraidy, M. M. (2002). Hybridity in cultural globalization. Communication Theory, 12(3), 316-339.

Kuhn, K. (2009). Consumerist lifestyles in the context of globalization: Investigating scenarios of homogenization, diversification and hybridization. The New Middle Classes, 5, 49-64.

Landler, M., \& Barbaro, M. (2006, August 2). Wal-Mart finds that its formula doesn't fit every culture. The New York Times, p. A1.

Lavallee, T. M., \& Boyer, M. A. (2006). Globalization and local governance: Implications from WalMart's expansion. International Studies Perspectives, 7, 254-266.

Lord, D., Moran, W., Parker, T., \& Sparks, L. (1988). Retailing on three continents: The discount food store operations of Albert Gubay. International Journal of Retailing, 3(3), 3-53.

Lyons, J. (2007, March 5). Southern hospitality: In Mexico, Wal-Mart is defying its critics. The Wall Street Journal, p. A1.

Marquard, W. H. (2006). Wal-Smart: What it really takes to profit in a Wal-Mart world. Boston: McGraw-Hill.

Martenson, R. (1987). Is standardisation of marketing feasible in culture-bound industries? A European case study. International Marketing Review, 4, 7-17.

Matusitz, J., \& Forrester, M. (2009). Successful glocalization practices: The case of Seiyu in Japan. Journal of Transnational Management, 14(2), 1-22.

Matusitz, J., \& Leanza, K. (2009). Wal-Mart: An analysis of the glocalization of the cathedral of consumption in China. Globalizations, 6(2), 187-205.

Matusitz, J., \& Reyers, A. (2010). A behemoth in India: Glocalization perspectives. South Asia Research, $30(3), 233-252$.

May, S. K., Cheney, G., \& Roper, J. (2007). The debate over corporate social responsibility. Oxford: Oxford University Press.

McGoldrick, P. J., \& Ho, S. L. (1992). International positioning: Japanese department stores in Hong Kong. European Journal of Marketing, 26(8), 61-73.

McWilliams, G. (2008, February 20). Wal-Mart evades global woes as net rises. Wall Street JournalEastern Edition, 251(41), p. A2.

Mexico's Retail Goliath. (2002). Business Latin. America, 37(11), 4.

Morais, R. C. (2004). One hot tamale. Forbes, 174(13), 137-147.

Moreau, R. (2009). Carrefour, casino and Wal-mart's expansion strategies in Latin America. Retail Digest, 44-49.

Muniz-Martinez, N. (1998). The internationalisation of European retailers in America: The US experience. International Journal of Retail and Distribution Management, 26(1), 29-37.

Nunn, N., \& Qian, N. (2010). The Columbian exchange: A history of disease, food, and ideas. Journal of Economic Perspectives, 24(2), 163-188.

O'Keefe, B., \& Burke, D. (2010). Meet the CEO of the biggest company on Earth. Fortune, 162(5), 80-94.

Robertson, R. (1994). Globalisation or glocalisation? Journal of International Communication, 1(1), 33-52.

Rogers, E. (2003). Diffusion of innovations. New York: Free Press.

Schwentesius, R., \& Gomez, M. A. (2002). Supermarkets in Mexico: Impacts on horticulture systems. Development Policy Review, 20, 487-502. 
Selling to the Developing World. (2003). Economist, 369(8354), p. 8.

Skonieczny, A. (2010). Interrupting inevitability: Globalization and resistance. Alternatives: Global, Local, Political, 35(1), p. 1.

Smith, G. (2006). In Mexico, Banco Wal-Mart. Business Week, 4010, 66-67.

Sparks, L. (1995). Reciprocal retail internationalisation: The Southland Corporation, Ito-Yokado and 7-Eleven convenience stores. In G. Akehurst \& N. Alexander (Eds.), The internationalisation of retailing (pp. 57-96). London: Frank Cass and Co.

Spulber, D. F. (2007). Global competitive strategy. Cambridge: Cambridge University Press.

Steil, B., \& Hinds, M. (2009). Money, markets, and sovereignty. Hartford, CT: Yale University Press.

Swanson, K. (2008). Kaplan AP human geography. New York: Kaplan Publishing.

Tegel, S. (2003). Every day higher sales: Mal-Mart Wunderkind Walmex shows them how it's done in a down economy: The Giant 24. Latin Trade, 4, 10-21.

The Economist. (2001, April 19). Mexico: Economic structure.

Tilly, C. (2005). Wal-Mart in Mexico: The limits of growth. In N. Lichtenstein (Ed.), The face of twentyfirst-century capitalism (pp. 189-209). New York: The New Press.

Tilly, C., \& Galván, J. L. Á. (2006). Lousy jobs, invisible unions: The Mexican retail sector in the age of globalization. International Labor and Working-Class History, 70, 61-85.

Treadgold, A. (1991). Dixons and Laura Ashley: Different routes to international growth. International Journal of Retail and Distribution Management, 19(4), 13-19.

Tyler, J. (2010). Wal-Mart's bank ambitions in Mexico. American Public Media, p. A1.

Weiner, T. (2003, December 6). Wal-Mart invades, and Mexico gladly surrenders. The New York Times, p. A1.

Welch, J., \& Welch, S. (2006). What's right about Wal-Mart. Business Week, 3982, 112.

Wiarda, H. J. (2007). Globalization: Universal trends, regional implications. Boston: Northeastern University Press.

Williams, D. C. (2002). Introduction: Communication perspectives on relationships between globalism and localism. Communication Studies, 53(1), 1-3.

Zimmerman, A., Bustillo, M., \& Lublin, J. S. (2008, November 22). Wal-Mart's Scott surprises with plan to retire as CEO. Wall Street Journal-Eastern Edition, 252(123), B1-B5.

Zimmerman, A., \& Hudson, K. (2006, April 17). Managing Wal-Mart. The Wall Street Journal, p. A1. 